\title{
PENGARUH LOGAM Li PADA ADSORPSI ATOM-ATOM H OLEH PERMUKAAN GRAFENA PLANAR
}

\author{
Theresia Sita Kusuma, Emdeniz, dan Syukri Arief \\ Jurusan Kimia, Fakultas Matematika dan Ilmu Pengetahuan Alam \\ Universitas Andalas, Padang
}

\begin{abstract}
Graphene has future prospect for electronics. By adding some substituents this material can be tuned to behave like a metal or semiconductor. In this investigation, a planar single layer of modified graphene, $\mathrm{C}_{24} \mathrm{H}_{12-\mathrm{m}} \mathrm{Li}_{\mathrm{m}}(\mathrm{m}=0,3,6$, and 12) consisted of seven six-member rings was used to adsorb the oncoming hydrogen (perpendicular to the surface, was defined as $\mathrm{H}_{\mathrm{ad}}$ ). A planar twolayer graphene $\mathrm{C}_{48} \mathrm{H}_{24}(7+7)$ was also included. To determine the adsorption models and the $\mathrm{H}_{\mathrm{ad}}$ couverage, a semiempiris Calzaferri program, works on pentium 4 windows 98, was used to optimize $\mathrm{nH}_{\mathrm{ad}}(\mathrm{n}=1,2$, and 3$)$ that reached the surfaces. The heat of $\mathrm{H}_{\mathrm{ad}}$ adsorption and the band gap of the surfaces were also computed. Results of these computations showed that: (1) the adsorption process was endothermic and Li reduced the heat of $\mathrm{H}_{\mathrm{ad}}$ adsorption on the surfaces. (2) $\mathrm{Li}$ reduced the band gap of the surfaces, so $\mathrm{C}_{24} \mathrm{H}_{12}$ was a semiconductor but $\mathrm{C}_{24} \mathrm{Li}_{12}$ a conductor. (3) The adsorbed $\mathrm{nH}_{\mathrm{ad}}$ always lowered the band gap of the surfaces, in exception of $\mathrm{C}_{24} \mathrm{Li}_{12}$ could be lower or higher. (4) Each atom on the surfaces, in exception hydrogen, might adsorb $\mathrm{nH}_{\mathrm{ad}}$ formed tilted (with $\mathrm{C}$ ) and lying down (with Li) surface complexes, and for $\mathrm{C}_{24} \mathrm{H}_{6} \mathrm{Li}_{6}$ an asymmetric twofold complex was also observed. (5) However, the $\mathrm{H}_{\mathrm{ad}}$ couverage was low, some $\mathrm{H}_{\mathrm{ad}}$ formed $\mathrm{H}_{2}$ and this was not observed on $\mathrm{C}_{24} \mathrm{H}_{6} \mathrm{Li}_{6}$. (6) $\mathrm{The}_{48} \mathrm{C}_{24} \mathrm{kept}$ an $\mathrm{H}_{2}$ molecule between layers. Thus, a new material $\mathrm{C}_{24} \mathrm{H}_{6} \mathrm{Li}_{6}$ which had two adsorption models, might increase the $\mathrm{H}_{\mathrm{ad}}$ couverage, but had lower conductivity than that of $\mathrm{C}_{24} \mathrm{H}_{12}$. On the other hand, it is necessary to study in more details the hydrogen storage between graphene layers.
\end{abstract}

Key words: graphene, adsorption, substituent

\section{DAFTAR PUSTAKA}

1. Zhao, X. B., Xiau, B., Fletcher, A. J., and Thomas, K. M., 2005, Hydrogen Adsorption on Functionalized Nanoporous Activated Carbons, J. Phys. Chem. B., 109: 8880-8888.

2. Park, K. A., Seo, K., and Lee, Y. H., 2005, Adsorption of Atomic Hydrogen on Single-Walled Carbon Nanotubes, J. Phys. Chem. B 2005.,109: 8967-8972.

3. Bermudez, V. M., 2005, Adsorption on Carbon Nanotubes Studied Using PolarizationModulated Infrared Reflection-Absorption Spectroscopy, J. Phys. Chem. B., 109: 9970-9979.

4. Albert, 2006, Pengaruh Li (Pengganti H) pada Adsorpsi Gas $\mathrm{H}_{2}$ oleh Siklasene dengan Empat Cincin, Thesis $S 2$..

5. Halford, B., 2006, Graphene Eyed as the Next Big Thing in Carbon-Based Electronics, Chemistry and Engeneering, April 17, 34.

6. Tachikawa, H., and Shimizu, A., 2005, Diffusion Dynamics of the $\mathrm{Li}^{+}$Ion on a Model Surface of Amorphous Carbons, J. Phys. Chem. B.,109: 13255-13262.

7. Zhu, Z. H., Lu, G. Q., Wang, F. Y., 2005, Why H Atom Prefers the on Top Site and Alkali Metals Favor the Middle Hollow Site on the Basal Plane of Graphite, J. Phys. Chem. B.,109: 7923-7927.

8. Kusuma, T. S., 2005, Unpublished Results. 
9. Stojkovic, D., Zhang, P., Lammert, P. E., and Crespi, V. H., 2003, Collective Stabilization of Hydrogen Chemisorption on Graphenic Surfaces, Phys. Rev. B., 68: 195406.

10. Van Lier, G., Ewels, C. P., Zuliani, F., de Vita, A., and Charlier, J. C., 2005, Theoretical Analysis of Fluorine Addition to Single-Walled Carbon Nanotubes: Functionalization Routes and Addition Patterns, J. Phys. Chem. B., 109: 6153-6158.

11. Calzaferri, G., and Brandle, M., 1992, QCPE, Program No QCMP 116, Indiana University, Bloomington, Indiana.

12. Acharya, C. K., and Turner, C. H., 2006, Stabilization of Platinum Clusters by Substitutional Boron Dopants in Carbon Supports, J. Phys. Chem. B., 110: 17706-17710.

13. Panggabean, Y., 2006, Adsorpsi Atom H pada Permukaan Grafit Planar Satu Lapisan $\mathrm{C}_{2} \mathrm{H}_{9} \mathrm{Li}_{3}$ dengan Metoda Calzaferri, Skripsi Sarjana Sains.

14. Kusuma, T. S., Emdeniz, dan Arif, S., 2007, Mempelajari Pengaruh Logam Li pada Adsorpsi Atom-Atom H oleh Permukaan Grafena Planar, Laporan Penelitian Research Grant TPSDP. 